\title{
STEROID HORMONES ASSAY ON ESTROGEN AND PROGESTERONE GROUP OCCURRENCES FATE AND PATHWAY DISTRIBUTIONS IN RIVER AND COASTAL ENVIRONMENT
}

\author{
CAROLYN PAYUS $* 1,3,4$, ALVIN OLIVER PAYUS ${ }^{2}$ AND MOH PAK YAN ${ }^{1}$
}

${ }^{1}$ Faculty of Science \& Natural Resources, ${ }^{2}$ Faculty of Medicine and Health Science, Universiti Malaysia Sabah (UMS), 88400 Kota Kinabalu, Sabah, Malaysia. ${ }^{3}$ Institute for the Future Initiatives, The University of Tokyo, 7-3-1 Hongo, Bunkyo-ku, Tokyo, 113-8654 Japan. ${ }^{4}$ Institute for the Advanced Study of Sustainability, United Nations University, 5-5370, Shibuya-ku, Tokyo, 150-8925 Japan.

*Corresponding author: cpayus@gmail.com

Submitted final draft: 30 June $2020 \quad$ Accepted: 25 July 2020

http://doi.org/10.46754/jssm.2021.04.009

\begin{abstract}
Birth control pills are one of the synthetic steroid hormones used as pharmaceutical drugs that are believed to cause higher transgender cases in the environment today, thus causing more cancer risk, such as vaginal and breast cancer, to human populations. This research aims to detect the occurrence and quantify the concentration of three types of steroid hormones (progesterone, $17 \propto$-ethynylestradiol and estrone) in the riverine and coastal environment. A method called dispersive liquid-liquid microextraction with solidification of floating organic drop followed by HPLC was used for hormone determination. Water samples were obtained through grab sampling along coastal and river courses. The results show a trend of hormone concentration, where progesterone had the highest occurrence, with total average of $0.11679 \pm 0.08796 \mathrm{ng} / \mathrm{mL}$, followed by $17 \propto$-ethynylestradiol at $0.53329 \pm 0.30904 \mathrm{ng} / \mathrm{mL}$, while estrone showed the least frequency of concentration with total average of $0.02406 \pm 0.00481 \mathrm{ng} / \mathrm{mL}$.
\end{abstract}

Keywords: Steroid hormone, estrogen, progesterone, estrone, $17 \propto$-ethynylestradiol, river, coastal.

\section{Introduction}

The occurrence of natural and synthetic steroids, especially in parts per trillion concentrations has worried researchers because these chemicals have shown to cause adverse impacts on aquatic organisms even in the very trace concentrations. The natural and synthetic discharge of sex steroids from menstruation and excretion will end up in domestic wastewater effluents, which flow into treatment plants and eventually into the lakes and rivers. The gradual buildup of these sex steroids drew wide concerns on their endocrinedisrupting effects and how they will affect the drinking water supply, since various studies have shown that they remain in wastewater even after treatment due to incomplete removal from the old conservative wastewater treatment system or from direct discharge into the watercourse (Weigel et al., 2012; Seiler, 2008). Previous studies on steroid hormones and their effects on the aquatic environment were found to be lacking compared to other more common water quality parameters studied, such as heavy metal contamination, fecal coliform contamination and nutrient contamination. On the other hand, there has been no environmental legislation that covers hormones and antibiotics in the context of environmental law up to this date, especially on developing a permissible limit or standard for this emerging endocrine disrupting compounds (EDCs) residues in the environment. Hence, the objective of this research is to determine the occurrence of steroid hormones and their pathway from waste and surface water environment and moving on to beaches and coastal environment.

The presence and occurrence of the steroid hormones are low in the environment, however, it is very unsafe and risky for humans and the ecosystem health, as the micro-constituent pollutants are capable of altering the functioning of the endocrine system in humans and wildlife by long term accumulation (Fuhrman et al., 2015). It is very toxic despite in very low 
concentration (ng/L), and will interfere with the production, release, transportation, metabolism process, binding, action or elimination of the natural hormones in the body (Kavlok, 2009). Steroids typically possess more strong physiological effects at very low concentrations via binding to nuclear receptors at nano- or picomolar levels and will affect the toxicity level (Segner et al., 2013). In addition, the excretion of steroids and their metabolites into the environment are due to their incomplete removal in wastewater treatment plants or direct discharge into watercourses (Weigel et al., 2012; Seiler, 2008). The most significant entry route for these compounds into aquatic environments are their release from wastewater treatment plants due to their conservative legacy systems (Lindqvist et al., 2005). Substantial amounts of medication are usually excreted unmodified and travel via urine and feces into wastewater (Jones et al., 2011), and as a result these compounds are normally detected at elevated levels in wastewater influents (Kolpin et al., 2012; Sacher et al., 2011). Therefore, it is necessary to develop a database that will document the occurrence of EDCs, especially for steroid hormones, in the environment and to understand the extent of this micro-pollutant transport of steroid hormones in the ecosystem, as it contributes long-term negative impacts on public health and nature.

The occurrence of steroid hormones in surface water has increased because of the release of treated or untreated sewage along the river and coastal ecosystems. Beaches or the coastal environment is the last extent point for steroid hormones discharge that can be reached by wastewater and surface water flow (Lagana et al., 2008;). Steroid hormones are expected to be detected in the river and coastal areas due to sewage effluents and leakage that will bring continuous accumulation in the ecosystems (Kolpin et al., 2012). Hence, this unique group of hazardous organic micro-pollutants is gradually becoming prominent as they could pose a new threat to the decline in water quality with their endocrine-disrupting effects on both humans and wildlife. Human excretion and menstrual flow are major sources of natural steroidal estrogens found in surface waters due to the lack of proper piping and sewage that causes waste to leak from housing areas, even from illegal homes and slums. Most of this domestic waste, which contains high amounts of steroidal estrogens, flow into the rivers and seas. This could be compounded by the fact that global consumption of estrogens had increased exponentially over the last 50 years because of contraceptives, menopausal therapies, as a treatment for some human cancers and as veterinary growth promoters. Estrogens are now considered to be the most prescribed drugs in the world (Guedes-Alonso et al., 2017). Steroids are among the major groups of chemicals that are categorized as endocrine disruptors (Zhang et al., 2013).

Natural and synthetic steroid hormones, such as estrone, estradiol and ethinyl estradiol are capable of acting as EDC in the environment. Metabolites of steroid hormones form glucuronides with specific enzymes in order to be excreted out of the human body in the form of water-soluble conjugates (Makin \& Gower, 2010). Glucuronides, which have a higher solubility in water, are excreted via the kidney while some is excreted in feces. In this modern medical science era, both natural and synthetic steroid hormones are widely used as contraceptive pills, infertility treatment, menstrual and menopausal hormonal treatment, hormone replacement therapy (HRT), to treat particular cancers (Zarzycki et al., 2009), growth enhancement for men and testosterone for male infertility prevention. Hence, these steroid hormones are excreted without control by humans and end up in the sewage system, and is listed as the main source of steroid hormone contamination in the environment (Liu et al., 2013). The research is significant in viewing analysis on the biosynthetic pathway of steroid hormone in the water system, specifically for riverine and coastal environments.

From the hypothesis of this study, natural and synthetic discharge of sex steroids from menstruation and excretion will end up in 
domestic wastewater effluents, which flow into treatment plants and eventually into the lakes and rivers. Therefore, this research is significant for water security studies to develop a database for the androgens and progestogens concentrations in the biosynthetic pathway in the water system. Specifically, for riverine and coastal environments that deal with nontraditional human waste contamination markers on steroid hormones. In addition, from the baseline data obtained, it is hoped to stimulate government action on the need for a new set of laws to limit concentration of hormones and antibiotics and combat this emerging threat to the health of aquatic environment.

\section{Materials and Methods}

A method called dispersive liquid-liquid micro extraction with solidification of floating organic drop followed by HPLC was performed for hormone determination. The HPLC system used is Agilent Technologies 1200 series equipped with VWD (UV-DAD) detector for detection of the steroid hormones. The water sample obtained through grab sampling along coastal and river courses. The river and coastal waterways chosen for sampling involved the Inanam River, Papar River, Sepanggar River, Moyog River, Sembulan River and to the end point of Tanjung Aru Beach. The study areas were selected based on their topographic location that is near to the main city, with heavily dense populated areas, surrounded by residential areas as well as hotels and a large number of leaky sewage collectors, as most the properties nearby are served by old and aging septic tanks. Each sampling area includes six sites along every drainage basin, where it meets at the Likas Bay and Tanjung Aru Beach. The sites have much-restricted water flows since the discharge is too shallow along the coastline. The chosen locations span from upstream to the downstream at which the river basins converge to flow out to the sea. Apart from that, the chosen rivers also receive water from the catchment point of resources for drinking water and consumption and are also the main locations where the wastewater treatment plants discharge their effluents. Steroid hormones were expected to be detected in the river and coastal area due to the sewerage effluent and leakage that will bring continuous accumulations in the ecosystem (Kolpin et al., 2012).

For the hormone steroid analysis, Dispersive Liquid-Liquid Micro Extraction based on Solidification Floating Organic Drop (DLLME-SFO) methodology was carried out for the steroid hormone extraction (Payus et al., 2016; Chang \& Huang, 2010). Before the extraction of steroid hormones, a mixture that contains a dispersive solvent and extraction solvent was injected into $5 \mathrm{~mL}$ of water sample spiked with $50 \mu \mathrm{g} / \mathrm{L}$ of analytes (Standard Stock solution of $17 \alpha$-ethynylestradiol). The dispersive solvent is methanol whereas the extraction solvent is 1-Undecanol. All water samples with analytes (Standard stock solution of $17 \alpha$-ethynylestradiol) undergo centrifugation at $4500 \mathrm{rpm}$ for 3 minutes. Liquid organic drop was floated on the surface of the water sample. The water sample was cooled in an ice bath for a few minutes until the frozen liquid organic drop was formed. The solid-liquid organic drop was then removed from the water sample using a customized scoop. The solid-liquid organic drop was melted rapidly at room temperature. In order to separate the water and organic solvent of the scooped melted solid organic drop, the whole drop of organic solvent was transferred to a microtube by using a syringe. Next, the organic solvent was transferred into an autosampler vial and mixed with dimethyl sulfoxide. The mixture was then injected into a High-Performance Liquid Chromatography (HPLC) system for the detection of steroid hormone (APHA, 2018).

Three replications for each water sample from each sampling location were involved in this study. Before the analysis of steroid hormone, standard stock solutions were prepared at a concentration of 2,000,000 ng/ $\mathrm{mL}$ in acetonitrile. The solutions were diluted to the suitable concentration by using acetonitrile and maintained at a temperature of $4^{\circ} \mathrm{C}$. HPLC Phenyl Column $(1.7 \mu \mathrm{m}, 2.1 \mathrm{~mm} \times 100 \mathrm{~mm})$ was chosen for separation of analytes. Column 
temperature was maintained at $30^{\circ} \mathrm{C}$ whereas the wavelength was adjusted to $280 \mathrm{~nm}$, which is the UV detector with fixed wavelength. The separation gradient is the acetonitrile-water mobile phase, in which it is started with $5 \%$ of acetonitrile and then increased slowly to $40 \%$ after 2 minutes, followed by a slight increase to $50 \%$ after 4 minutes, then finally increased to $60 \%$ after 1 minute. The flow rate was kept at $0.4 \mathrm{~mL} / \mathrm{min}$. all the mobile phases were pretreated by filtering through a $0.22 \mu \mathrm{m}$ membrane of nylon filter media. Samples were held in vials, whereas the injection volume was set at $25 \mu \mathrm{L}$ for each sample. All the Pyrex glassware, petri plates and forceps are sterilized by autoclaving for 15 -minutes at $121^{\circ} \mathrm{C}$. Extraction was carried out as early as possible to avoid addition of chemical preservatives. The water samples and standard solutions were run through the HPLC system to identify the peak and retention time of the steroid hormone concentrations (Payus et al., 2016).

\section{Results and Discussion}

The steroid hormones concentrations that managed to be detected in this research, are progesterone, $17 \propto$-ethynylestradiol and estrone. These were measured from the samples taken from the Inanam River, Moyog River, Sepanggar River, Sembulan River, Papar River to the end point of Likas Bay and Tanjung Aru Beach. The findings of the research for the occurrences and concentrations of the steroid hormones can be summarized in Table 1, Table 2 and Table 3, according to each river basin at the studied area, with each of the steroid hormone involved in the analysis.

Table 1: Minimum value, maximum value, mean and standard deviation of the trend detection of progesterone $(\mathrm{ng} / \mathrm{mL})$ in each of the river basins at the studied area

\begin{tabular}{lcccc}
\hline Location & Min Value & Max value & Mean & Standard Deviation \\
\hline Inanam River & 0.24660 & 0.41054 & 0.32300 & 0.04120 \\
Moyog River & 0.08828 & 0.19387 & 0.13048 & 0.02085 \\
Sepanggar River & 0.02350 & 0.05095 & 0.03815 & 0.02384 \\
Sembulan River & 0.01262 & 0.04128 & 0.01561 & 0.01508 \\
Papar River & 0.02668 & 0.14977 & 0.07671 & 0.02606 \\
Likas Bay & & & No Detection & \\
Tanjung Aru Beach & & & No Detection & \\
\hline
\end{tabular}

Table 2: Minimum value, maximum value, mean and standard deviation of the trend detection of $17 \propto-$ ethynylestradiol $(\mathrm{ng} / \mathrm{mL})$ in each of the river basins at the studied area

\begin{tabular}{lcccc}
\hline Location & Min Value & Max value & Mean & Standard Deviation \\
\hline Inanam River & 0.12880 & 0.16190 & 0.14694 & 0.01305 \\
Moyog River & 11.62375 & 13.19611 & 0.77497 & 0.12013 \\
Sepanggar River & \multicolumn{2}{c}{ No Detection } \\
Sembulan River & 0.22681 & 2.19559 & 0.90968 & 0.84139 \\
Papar River & \multicolumn{2}{c}{ No Detection } \\
Likas Bay & \multicolumn{2}{c}{ No Detection } \\
Tanjung Aru Beach & 0.25827 & 0.47821 & 0.30157 & 0.12233 \\
\hline
\end{tabular}


The findings show that the average concentration of the steroid hormone progesterone at all studied river basins and coastal sites are recorded at $0.11679 \pm$ $0.08796 \mathrm{ng} / \mathrm{mL}$, with a range of $0.01262 \mathrm{ng} /$ $\mathrm{mL}$ at the lowest to $0.41054 \mathrm{ng} / \mathrm{mL}$ at the highest concentration detected. The trend of detections showed the hormone progesterone had the highest occurrences compared to $17 \propto$-ethynylestradiol and estrone.

For the hormone steroid $17 \propto$ ethynylestradiol, total average concentrations recorded at $0.53329 \pm 0.30904 \mathrm{ng} / \mathrm{mL}$, with a range of concentration detections from the lowest of $0.12880 \mathrm{ng} / \mathrm{mL}$ to the highest concentration of $13.19611 \mathrm{ng} / \mathrm{mL}$. But $17 \propto$-ethynylestradiol steroid hormone was not detected in all river basins. The same situation was found for estrone: the hormone was not found in most rivers but only in Inanam River and Tanjung Aru Beach, with a total average concentration of $0.02406 \pm 0.00481 \mathrm{ng} / \mathrm{mL}$, with the lowest concentration recorded at $0.00014 \mathrm{ng} / \mathrm{mL}$ to the highest at $0.11510 \mathrm{ng} / \mathrm{mL}$. On the other hand, the concentration of steroid hormones saw an increasing pattern from upstream to downstream of the river and shows the least concentration of trend concentration at coastal waters. This might be due to the higher or lower occurrence of steroid concentration that the analyte in a sample could not be detected by the limit detection value (LOD) and limit of quantification (LOQ) in this analysis, with a probability that the concentration of the component in the material analyzed is greater than the blank sample (Baross et al., 2015). The research also showed that estrone has the least frequency of nondetection, followed by $17 \propto$-ethynylestradiol, whereas the progesterone reported having the greatest frequency of occurrences.

Comparisons of the steroid hormone concentrations and detections with previous studies, for progesterone, 17- $\alpha$ ethynylestradiol and estrone found that the level of detection in this study was lower, as shown in Table 4. Liu et al. (2011) detected progesterone at concentrations 0.5 to $2.5 \mathrm{ng} / \mathrm{L}$ in the river which receives heavy load of effluents from a nearby WWTP, and domestic wastewater forms the majority of the effluent. Machado et al. (2014) also detected higher progesterone level at 60 and $450 \mathrm{ng} / \mathrm{L}$ and argued that the different profiles could be due to the discharge of a mixture of treated wastewater and naturally attenuated untreated wastewater during the study period. This has also been expected since it is a menstrual cycle-related hormone and released throughout the ovarian cycle, causing higher concentrations of this hormone to be released in wastewater (Machado et al., 2014; Liu et al., 2011; Chang et al., 2011). For 17- $\alpha$ ethynylestradiol in this research, it is of utmost concern to assess its impact on to the environment, especially when significant amounts were detected in a better quality upstream water. When compared with previous studies shown in Table 4 done by De

Table 3: Minimum value, maximum value, mean and standard deviation of the trend detection of estrone $(\mathrm{ng} / \mathrm{mL})$ in each of the river basins at the studied area

\begin{tabular}{|c|c|c|c|c|}
\hline Location & Min Value & $\begin{array}{c}\text { Max } \\
\text { value }\end{array}$ & Mean & Standard Deviation \\
\hline Inanam River & 0.06680 & 0.11510 & 0.04977 & 0.01123 \\
\hline Moyog River & \multicolumn{4}{|c|}{ No Detection } \\
\hline Sepanggar River & \multicolumn{4}{|c|}{ No Detection } \\
\hline Sembulan River & \multicolumn{4}{|c|}{ No Detection } \\
\hline Papar River & \multicolumn{4}{|c|}{ No Detection } \\
\hline Likas Bay & \multicolumn{4}{|c|}{ No Detection } \\
\hline Tanjung Aru Beach & 0.00014 & 0.00014 & 0.00014 & 0.00000 \\
\hline
\end{tabular}


Table 4: Comparison of progesterone, 17- $\alpha$ ethynylestradiol and estrone concentrations $(\mathrm{ng} / \mathrm{mL})$ in this research compared with previous studies

\begin{tabular}{|c|c|c|}
\hline $\begin{array}{c}\text { Reference } \\
\text { (Literatures) }\end{array}$ & $\begin{array}{c}\text { Detection Level } \\
\text { (ng/L) }\end{array}$ & $\begin{array}{c}\text { Study Location } \\
\text { (Country) }\end{array}$ \\
\hline \multicolumn{3}{|c|}{ Progesterone } \\
\hline In this Research & $0.01-0.41$ & Malaysia \\
\hline Machado et al. (2014) & $60-450$ & Brazil \\
\hline Liu et al. (2012) & 2.5 & China \\
\hline Chang et al. (2011) & $\begin{array}{c}\text { River A } \\
0.3-1.2 \\
\text { River B } \\
0.1-0.9\end{array}$ & China \\
\hline \multicolumn{3}{|c|}{ 17- $\alpha$ ethynylestradiol } \\
\hline In this Research & $0.13-13.20$ & Malaysia \\
\hline De Mes et al. (2005) & $\begin{array}{c}\text { River (Meuse) } \\
0.2 \\
\text { River (Rhine) } \\
1.2-4.3\end{array}$ & Netherlands \\
\hline Rao et al. (2013) & $1.55-24.4$ & China \\
\hline Lei et al. (2009) & $\begin{array}{c}\text { River (Beitang) } \\
1.64-24.4 \\
\text { River (Dagu) } \\
\text { No detection }-35.6 \\
\text { River (Yongding New) } \\
\text { No detection }-12.0\end{array}$ & China \\
\hline \multicolumn{3}{|c|}{ Estrone } \\
\hline In this Research & $0.0001-0.1151$ & Malaysia \\
\hline Liu et al. (2011) & $\begin{array}{c}\text { River (Upstream) } \\
6.0 \\
\text { River (Downstream) } \\
13.3\end{array}$ & China \\
\hline Xin Zhou et al. (2011) & $14.0-180.0$ & China \\
\hline Chen et al. (2010) & $\begin{array}{c}\text { Creek (Wulo) } \\
\text { Upstream } \\
376.1 \\
\text { Downstream } \\
87.7\end{array}$ & China \\
\hline
\end{tabular}

Mes et al. 2005; Rao et al. 2013; Lei et al. 2009, the loading of $17-\alpha$ ethynylestradiol pollution in the water system should spark concern and mitigation measures should be taken in order to prevent the aquatic systems and organisms from endocrine-disrupting effects caused by these estrogen mimics, as the 17- $\alpha$ ethynylestradiol is a synthetic steroid hormone and it is more potent and stable compared to the others that can cause more severe endocrine disrupting effects. For estrone, in this study it shows least occurrence as compared to the previous studies by Liu et 
al. 2011; Xin Zhou et al. 2011; and Chen et al. 2010 .

According to Kabir et al. (2015), progesterone and synthetic progestins were mostly detected when analyzed and occurred in the low $\mathrm{ng} / \mathrm{mL}$ range in wastewater and surface water. It is important to note that many of the used progestins have never been analyzed and their fate in wastewater treatment and the aquatic environment is poorly known (Karl, 2015). The ovaries produce progesterone even during the follicular phase of the cycle, and is also synthetically produced for birth control pills (Peng et al., 2014). According to Karl (2015), progesterone excreted from our body through urine and feces. The analysis by Payus et al. (2016) found that if there was a higher amount of fecal coliform then there will be fewer progesterone concentrations detected because fecal coliforms can degrade progesterone. In conclusion, the presence of progesterone is from women using contraceptive pills or through the menstrual cycle and estrous.

The non-detection concentration of progesterone could be due to the degradation of the steroid hormone. Photodegradation is an abiotic degradation pathway that takes place in natural water. Indirect photodegradation occurs when another compound absorbs light, becomes excited and reacts with the organic contaminant, while direct photodegradation occurs when organic contaminants absorb light, become excited and undergo chemical changes (Khetan \& Collins, 2007). Unsaturated molecules can absorb light in the 200-700 $\mathrm{nm}$ range, which includes all visible light and much of the low energy UV spectrum (Vialaton \& Richard, 2002). Natural water usually contains many unsaturated molecules for example, dissolved organic matter and other reactive intermediates, such as nitrate and nitrite, that absorb light in this range (Lin \& Reinhard, 2005). As a result, natural water bodies have been described as "large photochemical reactor systems". Because progesterone is an unsaturated molecule, it has the potential to undergo direct and indirect photodegradation. Progesterone's biological damage starts in transit to the sewage treatment plant (WWTP) in the sewer, as this channel is known to become an active bioreactor that contains natural biofilms with varying metabolic abilities (Jelic et al., 2015). Generally, the transformation of progesterone may be caused by the process of biotic or abiotic degeneration of steroids and associated toxicity (Jasper et al., 2017). The removal of organic pollutants at WWTPs is a complex process with many plausible mechanisms (Evgenidou et al., 2015). The main transport route for this compound to the environment is through WWTP, where it may be only partially removed.

Detection of $17-\alpha$ ethynylestradiol has always been the major concern as it has high resistance towards degradation and has high tendency to absorb organic matter, accumulate in sediment and concentrate in biota (Ahmad et al., 2014). The $17 \alpha$-ethynylestradiol is also known as a synthetic estrogen compound that can be found in drugs and contraceptive pills. Wastewater effluent containing estrogen compounds are discharged into the river, while the sludge is used as fertilizer. Steroid hormone $17-\alpha$ ethynylestradiol is insoluble in water but will dissolve in ethanol, and can resist the biodegradation process due to its physicochemical properties as a nonpolar and hydrophobic organic compound with low volatility. It has a higher possibility to bind with the estrogen receptor too in the human body compared to estradiol (Zhuo et al., 2019; Sanaz et al., 2016; Ahmad et al., 2014). From these findings, it shows that $17-\alpha$ ethynylestradiol is a more powerful estrogenic compound in stimulating the estrogenic response compared to estradiol that can be naturally produced (Lima $e t$ $a l ., 2012)$. It was widely used as contraceptive pills because 17- $\alpha$ ethynylestradiol has a high resistance to the biodegradation process, as well as greater oral bioavailability in the human body. Therefore, it is not surprising to find $17-\alpha$ ethynylestradiol detection in the river ecosystem as it was allowed to flow into the water body through domestic wastewater. A study also found that 17- $\alpha$ ethynylestradiol was highly 
stable towards oxidation, which means it is more resistant against degradation due to the presence of the ethynyl group in the $17^{\text {th }}$ position in the chemical structure (Li et al., 2013). When the hormones are excreted from the human body or undergo surface runoff from agricultural activity such as from fertilizer, it will flow into the water body and some might penetrate through the groundwater system. Human waste such as urine is considered one of the main sources of 17- $\alpha$ ethynylestradiol. However, the hormone excretions from the human body have been metabolized to form biologically inactive and water-soluble sulfate (Andrew et al., 2010).

The quantity of hormone secretion depends on the sex, hormonal status, stage of menstruation, consumption of contraceptive pills and pregnancy. Besides, waste discharged from factories producing these synthetic hormones is also the main contributor to the high hormone concentration in water sources especially estrogen compound. As a result, water bodies can contain large loads of estrogen compounds, where a small amount may be absorbed by sediments and stay for a long period. Besides, other factors could contribute to the high concentration of the hormone in the water body which includes hydrologic flowpaths such as infiltration and vertical drainage. The wide consumption of both natural and synthetic estrogens by humans has resulted in an increase of 17- $\alpha$ ethynylestradiol presence and availability in the environment. The increase of population in an area has led to an irregular distribution of these pollutants (Sengul, 2016). Ismail et al. (2014) found that even $100 \mathrm{~km}$ away from the sewage effluent source, steroid hormones such as 17- $\alpha$ ethynylestradiol can still be detected. Pollutants may have been diluted when they reach coastal areas, as waters there are well mixed, which might cause scattering of 17- $\alpha$ ethynylestradiol glucuronides (Emnet et al., 2015). Nonetheless, a low concentration of steroid hormone occurrence is still capable of affecting both the environment and human health even in trace concentrations (Barber et al., 2000).
In this study, estrone was detected only in Inanam River and Tanjung Aru Beach. Generally, estrone is one of the estrogens groups that can be found widely in the aquatic environment and the most abundant natural estrogen in aquatic systems. However, it seemed that in this research estrone had the opposite fate. One of the reasons is because coastal waters are well mixed and causes scattering of estrone glucuronides (Emnet et al., 2015). This can explain the low concentration of estrone that was detected and it was mostly below LOD. Humans are not the only ones that excrete large amounts of estrone in glucuronide- and sulfateconjugated forms via urine, but also animals (Sarmah et al., 2006), which normally could be discharged from the major storm drains (Ahmad et al., 2014). Non-detection of estrone could also be due to the photodegradation that degraded estrone rapidly under simulated sunlight (Combalbert \& Hernandez-Raquet, 2010). This is due to the fact that there is an absence of no ethinyl group in estrone which makes it appear less potent as a natural estrogen as compared to synthetic estrogen. Therefore, estrone tends to degrade faster and does not appear in the environment, which explains why there were so many non-detected concentrations of estrone in the study areas. Estrone has high photon absorption capability and will be degraded by UVC and UVA direct photolysis, in which the photon energy is absorbed by the estrogen molecule, undergoes excitation and irreversible reactions that will break down molecular bonds, thus reduced the estrone (Ma et al., 2015).

In comparison of estrone and 17- $\alpha$ ethynylestradiol, degradation of estrone does not have strong estrogenic activity observed but $17-\alpha$ ethynylestradiol is said to be more recalcitrant in the water body (Moschet \& Hollender, 2009). This is because $17-\alpha$ ethynylestradiol has an ethinyl group at C-17 atom as shown in Figure 1 whereas estrone does not have. This feature prevents the oxidation of this $\mathrm{C}$-atom, hence, 17- $\alpha$ ethynylestradiol has a greater influence on the environment for the reason of its stability in the water body (Li et al., 2013). Unlike synthetic estrogen 17- $\alpha$ ethynylestradiol, the estrone 
that acts as the natural female sex hormone is not as potent as the 17- $\alpha$ ethynylestradiol. In other words, 17- $\alpha$ ethynylestradiol is more persistent compared to estrone. According to the physicochemical properties of the synthetic estrogens, 17- $\alpha$ ethynylestradiol is a nonpolar and hydrophobic organic compound with low volatility and is more biodegradation resistant (Feng et al., 2010). This can explain why 17- $\alpha$ ethynylestradiol in this study were recorded more than the estrone. Most of the study areas show higher concentrations of 17- $\alpha$ ethynylestradiol, whereas estrone was detected at only two sites. Previous studies reported similar results. Emnet et al. (2015), did not detect estrone in all the water samples, even in the sewage effluent, whereas 17- $\alpha$ ethynylestradiol was detected in all the samples. Therefore, detection of synthetic $17-\alpha$ ethynylestradiol is much easier than the natural and non-synthetic steroid hormone, estrone.

Whidbey et al. (2012) reported that estrone photodegraded faster than 17- $\alpha$ ethynylestradiol, which means estrone has a shorter half-life. This is since 17- $\alpha$ ethynylestradiol has an ethinyl group, which is a triple-bond attached at the $\mathrm{C}-17$ atom. Generally, the strength of the bond in a chemical structure increases with the increasing number of bonds. Single bond $<$ double bond $<$ triple bond. This also explains why $17-\alpha$ ethynylestradiol is more difficult to be broken down and has a slower rate of degradation. Ma et al. (2015) found that the conversion sequence of estrogens was estrone $>$ 17- $\alpha$ ethynylestradiol under the direct radiation of mainly UVA and UVC. It also found that estrone has a higher photon absorption capability at $0.042 \mathrm{~cm}^{-1}$, which is $0.026 \mathrm{~cm}^{-1}$ stronger than 17- $\alpha$ ethynylestradiol. Moreover, natural sunlight has been shown to degrade estrogens to some extent, particularly in seawater (Xiaolin et al., 2013). Based on a study done by Kabir et al (2015), wastewater treatment plants removed estrone and 17- $\alpha$ ethynylestradiol at efficiencies of $93.7 \%$ and $71.2 \%$ respectively. Hence, the occurrence of estrone in the environment will be lower as compared to 17- $\alpha$ ethynylestradiol. Higher distribution of $17-\alpha$ ethynylestradiol in the environment than estrone can most probably be explained by the rapid use of contraceptive pills in the modern era of medical technology (Elsa et al., 2014). Overall, one of the main characteristics that are associated with the use of contraceptives is the high $17-\alpha$ ethynylestradiol degradation resistance and higher oral bioavailability in the human body (Gallo et al., 2016). However, the drawback of this characteristic is 17- $\alpha$ ethynylestradiol tends to remain longer in the environment and thus cause adverse effects to the human health and ecosystem. The 17- $\alpha$ ethynylestradiol ranked highest in terms of estrogenic potency during in vitro tests as compared to other natural estrogens, such as E1 (Gorga et al., 2012).

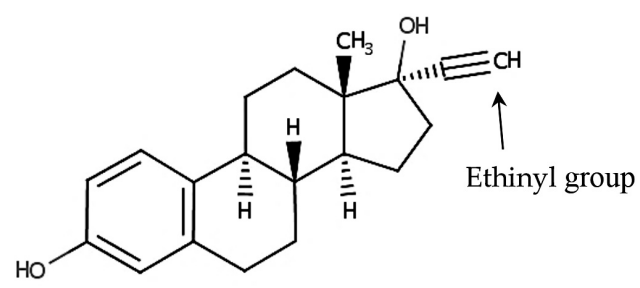

Figure 1: Chemical structure of 17 $\alpha$-ethynylestradiol (Source: Canadian Institutes of Health Research, 2013) 


\section{Conclusion}

The average concentration of the steroid hormone progesterone at all studied riverine and coastal environments are recorded at $116.79 \pm 87.96 \mathrm{ng} /$ $\mathrm{mL}$, with concentrations ranging from $12.62 \mathrm{ng} /$ $\mathrm{mL}$ to $410.54 \mathrm{ng} / \mathrm{mL} ; 17 \propto$-ethynylestradiol at $533.29 \pm 309.04 \mathrm{ng} / \mathrm{mL}$, range of concentrations from $128.80 \mathrm{ng} / \mathrm{mL}$ to $2195.59 \mathrm{ng} / \mathrm{mL}$; and estrone $24.06 \pm 4.81 \mathrm{ng} / \mathrm{mL}$, range from $0.14 \mathrm{ng} /$ $\mathrm{mL}$ to $115.10 \mathrm{ng} / \mathrm{mL}$ of concentrations. These results are alarming as the steroid hormones are still present despite going through wastewater treatment and reaching the coast, which is at the very end point of surface water. Future studies in monitoring the occurrence and emergence of these hormones should be done more often in the future. Monitoring for estrogenic concentration or other steroid hormones and hazardous organic micro-pollutants in the environment is needed because these compounds can undergo sorption and conversion, and even in trace-level concentrations could badly affect the water ecosystem.

\section{Acknowledgements}

This study is financially supported by the Ministry of Higher Education, Malaysia (MOHE) through Fundamental Research Grants (FRG0456), another grant from Niche Research Grant Scheme (NRGS0005), Japan Society for the Promotion of Science (JSPS) and Universiti Malaysia Sabah (UMS) Grant (SBK0237). It is part of Research Project of United Nations University-Institute for Advanced Study of Sustainability in collaboration with University of Tokyo. Great acknowledgment to all our students involved during the entire work of this research project, namely Camer, Max, Gwen, Jane, Dalilah, Syamilah, Yajri, Joyce, Myra and Siti Aminah.

\section{References}

Ahmad, Z. A., Aida, S. S., \& Sarva. M. P. (2014). Occurrence of $17 \alpha$-ethynylestradiol (EE2) in the environment and effect on exposed biota: A review. Environmental International, 69(9), 104-119.

Andrew, M. N., O’Connor, W. A., Dunstan, R. H., \& MacFarlane, G. R. (2010). Exposure to $17 \alpha$ - ethynylestradiol causes dose and temporally dependent changes in intersex, females and vitellogenin production in the Sydney Rock oyster. Ecotoxicology, 19(8), 40-51.

APHA. (2018). Standard methods for the examination of water and wastewater. Washington, D.C.: APHA.

Barber, L. B., Brown, G. K., \& Zaugg, S. D. (2000). Analysis of environmental endocrine disruptors. New York: Oxford University Press.

Baross, L. A., Tufik, S., \& Andersen, M. L. (2015). The role of progesterone in memory: An overview of three decades. Neuroscience and Biobehavioural Reviews, 49, 193-204.

Chang, C. S., \& Huang, S. D. (2010). Determination of the steroid hormone levels in water samples by dispersive liquidLiquid microextraction with solidification of a floating organic drop followed by high-performance liquid chromatography. Analytica Chimica Acta, 662, 39-43.

Chang, H., Wan, Y., Wu, S. M., Fan, Z. L., \& Hu, J. Y. (2011). Occurrence of androgens and progestogens in wastewater treatment plants and receiving river waters: Comparison to estrogens. Water Research, 45, 732-740.

Chen, T. S., Chen, T. C., Yeh, K. J. C., Chao, H. R., Liaw, E. T., Hsieh, C. Y., Chen, K. C., Hsieh, L. T., \& Yeh, Y.-L. (2010). High estrogen concentrations in receiving river discharge from a concentrated livestock feedlot. Science of the Total Environment, 408, 3223-3230.

Combalbert, S., \& Hernandez-Raquet, G. (2010). Occurrence, fate, and biodegradation of estrogens in sewage and manure. Applied Microbiology and Biotechnology, 86, 16711692. 
De Mes, T., Zeeman, G., \& Lettinga, G. (2005). Occurrence and fate of estrone, 17 ssestradiol and 17 alpha-ethynylestradiol in STPs for domestic wastewater. Reviews in Environmental Science and Bio/Technology, 4(4), 275-311.

Elsa, C. C., Casandra, O. B., Juan, J. B., \& Maria, C. G. (2014). Description of the retention and peak profile for chromolithc columns in isocratic and gradient elution using mobile phase composition and flow rate as factors. Journal of Environmental Monitoring, 1(9), 194-210.

Emnet, P., Gaw, S., Northcott, G., Storey, B., \& Graham, L. (2015). Personal care products and steroid hormones in the Antarctic coastal environment associated with two Antarctic Research Stations, McMurdo Station and Scott Base. Environmental Research, 136, 331-342.

Evgenidou, E. N., Konstantinou, I. K., \& Lambropoulou, D. A. (2015). Occurrence and removal of transformation products of PPCPs and Illicit Drugs in wastewaters: A review. Science of Total Environment, 505, 905-926.

Feng, Y., Zhang, Z., Gao, P., Su, H., Yu, Y., \& Ren, N. (2010). Adsorption behavior of EE2 (17 $\alpha$-ethinylestradiol) onto the inactivated sewage sludge: Kinetic, thermodynamics and influence factors. Journal of Hazardous Materials, 175, 970-976.

Fuhrman, Vivian F., Tal, A., \& Arnon, S. (2015). Why endocrine disrupting chemicals (EDCs) challenge traditional risk assessment and how to respond. Journal of Hazardous Materials, 286, 589-611.

Gallo, M. V., Ravenscroft, J., Carpenter, D. O., Frye, C., Cook, B., \& Schell, L. M. (2016). Endocrine disrupting chemicals and ovulation: Is there a relationship? Environmental Research, 151, 410-418.

Gorga, M., Petrovic, M., \& Barcelo, D. (2013). Multi-residue analytical method for the determination of endocrine disruptors and related compounds in river and waste water using dual column liquid chromatography switching system coupled to mass spectrometry. Journal of Chromatography A, 1295, 57-66.

Guedes-Alonso, R., Sosa-Ferrera, Z., \& Santana-Rodriguez, J. J. (2017). Determination of steroid hormones in fish tissues by microwave-assisted extraction coupled to ultra-high performance liquid chromatography tandem mass spectrometry. Food Chemistry, 237, 1012-1020.

Ismail, R., Lee, H. Y., Mahyudin, N. A., \& Abu Bakar, F. (2014). Linearity study on detection and quantification limits for the determination of avermectins using linear regression. Journal of Food and Drug Analysis, 22(4), 407-412.

Jelic, A., Rodriguez-Mozaz, S., Barceló, D., \& Gutierrez, O. (2015). Impact of in-sewer transformation on 43 pharmaceuticals in a pressurized sewer under anaerobic conditions. Water Resources, 68, 98-108.

Jasper, O. O., Abdul Chaundaly, J., Pablo, C., John, S. P., \& Mark, D. S. (2017). Progesterone potentially degrades to potent androgens in surface waters. Science of the Total Environment, 579, 1876-1884.

Kabir, E. R., Rahman, M. S., \& Rahman, Imon. (2015). A review on endocrine disruptors and their possible impacts on human health. Environmental Toxicology and Pharmacology, 40, 241-258.

Karl, F. (2015). Progestins as endocrine disruptive in aquatic ecosystems: Concentrations, effects and risk assessment. Environmental International, 84, 115-130.

Kavlock, R. (2009). Overview of endocrine disruptor research activity in the United States. Chemosphere, 39, 1227-36.

Khetan, S. K., \& Collins, T. J. (2007). Human pharmaceuticals in the aquatic environment: A challenge to green chemistry. Chemical Reviews, 107, 2319- 2364.

Kolpin, D. W., Furlong, E. T., Meyer, M. T., Thurman, E. M., Zaugg, S., Barber, L. B., 
\& Buxton, H. T. (2012). Pharmaceuticals, hormones, and other organic wastewater contaminants in US streams, 1999-2000: A national reconnaissance. Journal of Environmental Science and Technology, 36, 1202-1211.

Lagana, A., Bacaloni, A., Fago, G., \& Marino, A. (2008). Trace analysis of estrogenic chemicals in sewage effluent using liquid chromatography combined with tandem mass spectrometry. Journal of Rapid Communications in Mass Spectrometry, 14, 401-407.

Lei, B. L., Huang, S. B., Zhou, Y. Q., Wang, D. H., \& Wang, Z. J. (2009). Levels of six estrogens in water and sediment from three rivers in Tianjin area, China. Chemosphere, $76,36-42$.

Li, J., Jiang, L., Liu, X., \& Lv, J. (2013). Adsorption and aerobic biodegradation of four selected endocrine disrupting chemicals in soil - water system. International Biodeterioration Biodegradation, 76(1), 3-7.

Lima, D. L. D., Schneider, R. J., \& Esteves, V. I. (2012). Sorption behavior of EE2 on soils subjected to different long-term organic amendments. Science of Total Environment, 423(6), 120-4.

Lin, A. Y. C., \& Reinhard, M. (2005). Photodegradation of common environmental pharmaceuticals and estrogens in river water. Environmental Toxicology and Chemistry, 24, 1303-1309.

Lindqvist, L., Tuhkanen, T., \& Kronberg, L. (2005). Occurrence of acidic pharmaceuticals in raw and treated sewages and in receiving waters. Journal of Water Research, 39, 2219-2228.

Liu, S., Ying, G. G., Zhao, J. L., Chen, F., Chen, B., Zhou, L. J., \& Lai, H. J. (2011). Trace analysis of 28 steroids in surface water, wastewater and sludge samples by rapid resolution liquid chromatographyelectrospray ionization tandem mass spectrometry. Journal of Chromatography A, 1218, 1367-1378.

Liu, S., Ying, G. G., Zhou, L. J., Zhang, R. Q., Chen, Z. F., \& Lai, H. J. (2012). Steroids in a typical swine farm and their release into the environment. Water Research, 46, 37543768 .

Liu, S., Ying, G. G., Zhou, L. J., Zhang, R. Q., Chen, Z. F., \& Lai, H. J. (2013). Steroids in a typical swine farm and their release into the environment. Water Research, 46, 37543768 .

Ma, Y. C., \& Kim, H. Y. (1997). Determination of steroids by liquid chromatography/mass spectrometry. American Society for Mass Spectrometry, 8, 1010-1020.

Machado, K. S., Cardoso, F. D., Azevedo, J. C. R., \& Braga, C. B. (2014). Occurrence of female sexual hormones in the Iguazu river basin, Curitiba, Parana State, Brazil. Acta Scientiarum, 36(3), 421-427.

Makin, H. L. J., \& Gower, D. B. (2010). Steroid Analysis. Glasgow, UK: Springer Science \& Business Media B.V.

Moschet, C., \& Hollender, J. (2009). Microbial degradation of steroid hormones in the environment and technical systems. Switzerland: Swiss Federal Institute of Technology, Institute of Biogeochemistry and Pollutant Dynamics.

Payus, C., Camer, J., Vun, L. W., Tan, W. H., \& Wong, N. K. (2016). Occurrence of steroid sex hormone progesterone in influent and effluent of oxidation pond and the river outlet of waste water treatment case study. Journal of Environmental Science and Technology, 9, 399-406.

Peng, F. Q., Ying, G. G., Yang, B., Liu, S., Lai, H. J., Liu, Y. S., \& Zhou, G. J. (2014). Biotransformation of progesterone and norgestrel by two freshwater microalgae (Scenedesmus obliquus and Chlorella pyrenoidosa): Transformation kinetics and products identification. Chemosphere, 95, 581-588. 
Rao, K., Lei, B., Na, L., Mei, M., \& Wang, Z. (2013). Determination of estrogens and estrogenic activities in water from three rivers in Tianjin, China. Journal of Environmental Sciences, 25(6), 1164-1171.

Sacher, F., Lange, F. T., Brauch, H. J., \& Blankenhorn, I. (2011). Pharmaceuticals in ground waters: Analytical methods and results of a monitoring program in Baden-Wurttemberg, Germany. Journal of Chromatography A, 938, 199-210.

Sanaz, A., Prasher, S. O., ElSayed, E., Qi, Z., \& Patel, R. M. (2016). Effect of biochar on the fate and transport of manureborne progesterone in soil. Ecological Engineering, 97, 231-241.

Sarmah, A. K., Northcott, G. L., Leusch, F. D. L., \& Tremblay, L. A. (2006). A survey of endocrine disrupting chemicals (EDCs) in municipal sewage and animal waste effluents in the Waikato Region of New Zealand. Science of the Total Environment, 355, 135-144.

Segner, H., Caroll, K., Fenske, M., Janssen, C. R., Maack, G., Pascoe, D., Shafers, C., Vandenbergh, G. F., Watts, M., \& Wenzel, A. (2013). Identification of endocrinedisrupting effects in aquatic vertebrates and invertebrates: Report from the European IDEA project. Journal of Ecotoxicology and Environmental Safety, 54, 302-314.

Seiler, J. P. (2008). Pharmacodynamic activities of drug and ecotoxicology- can the two be connected. Journal of Toxicology Letters, 131, 137-143.

Sengul, U. (2016). Comparing determination methods of detection and quantification limits for aflatoxin analysis in hazelnut. Journal of Food and Drug Analysis, 24(1), 56-62.

Vialaton, D., \& Richard, C. (2002). Phototransformation of aromatic pollutants in solar light: Photolysis versus photosensitized reactions under natural water conditions. Aquatic Sciences, 64, 207-215.
Weigel, S., Kuhlmann, J., \& Huhnerfuss, H. (2012). Drugs and personal care products as ubiquitous pollutants: Occurrence and distribution of clofibric acid, caffeine and DEET in the North Sea. The Science of the Total Environment, 295, 131-141.

Whidbey, C. M., Daumit, K. E., Nguyen, T. H., Ashworth, D. D., Davis, J. C., \& Latch, D. E. (2012). Photochemical induced changes of in vitro estrogenic activity of steroid hormones. Water Research, 46, 5287-5296.

Xiaolin, L., Wei, Z., \& Walton, R. K. (2013). Occurrence and removal of pharmaceutical and hormone contaminants in rural wastewater treatment lagoons. Science of the Total Environment, 2(3), 22-28.

Xin Zhou, L., Ziru, W., Jiantao, T., Liju, T., \& Zhao, Z. (2011). Distribution of estrogens along Licun River in Qingdao, China. Procedia Environmental Sciences, 10, 1876-1880.

Zarzycki, P. K., Włodarczyk, E., \& Baran, M. J. (2009). Determination of endocrine disrupting compounds using temperaturedependent inclusion chromatography: II. Fast screening of free steroids and related low-molecular-mass compounds fraction in the environmental samples derived from surface waters, treated and untreated sewage waters as well as activated sludge material. Journal of Chromatography A, 1216(44), 7612-7622.

Zhang, X., Gao, Y., Li, Q., Li, G., Guo, Q., \& Yan, C. (2013). Estrogenic compounds and estrogenicity in surface water, sediments, and organisms from Yundang Lagoon in Xiamen, China. Archives of Environmental Contamination and Toxicology, 61(1), 93100 .

Zhuo, W., Jim, J. W., Hernandez, A. B., Warren, A., Jong-hwan, P., Meng, Y., Dodla, S. K., \& Jeong, C. (2019). Effect of biochar amendment on sorption-desorption and dissipation of $17 \alpha$-ethinylestradiol in sandy loam and clay soils. Science of the Total Environment, 686, 959-967. 